\title{
Еволюція поняття «подвійний синтаксичний зв'язок» в українському мовознавстві
}

\author{
НАТАЛЯ КОБЧЕНКО \\ Кафедра української мови, Національний університет \\ «Києво-Могилянська академія», вул. Сковороди, 2, UA-04655 Київ \\ E-mail:n.kobchenko@ukma.edu.ua
}

(Received: 17 October 2016; accepted: 30 November 2016)

\begin{abstract}
One of the topical problems of modern grammar is the qualification of doublesyntactic connection. Its nature conforms to none of the features of syntactic connection on the axis of closeness/openness. The problem of the particularity of this syntactic phenomenon appeared in the early twentieth century but it is still not resolved. The purpose of this paper is to clarify the conditions for the birth of the idea of double-syntactic connection and to review the evolution of this phenomenon in Ukrainian and Russian scholarly works. As the analysis demonstrates, the double-syntactic connection does not determine a single phenomenon but it includes a set of phenomena. It is a type that combines different varieties of syntactic connection according to their common features, such as three-member-construction and the complex realization of the syntactic connection. Various linguists have interpreted the patterns of the establishment of that phenomenon and the forms of its realization in different ways. The prospective of our study is to define grammatical markers of the double-syntactic connection and to describe the structure of the constructions in which it appears.

Keywords: double-syntactic connection, semi-predicative syntactic connection, double predicate, predicative attribute, infinitive
\end{abstract}

Науковці всіх граматичних шкіл і напрямків практично одностайні в тому, що предметом вивчення в синтаксисі з-поміж інших $\epsilon$ й синтаксичний зв'язок. Така позиція $\epsilon$ цілком обгрунтованою, адже саме синтаксичні зв'язки організовують формально-граматичну структуру центральної мовної одиниці - речення.

Студіювання синтаксичних зв'язків почалося разом із виокремленням синтаксису в самостійну галузь мовознавства й триває досі. Якщо синтаксичні розділи перших слов'янських граматик були спрямовані лише на з'ясування специфіки поєднання слів у речення, то граматики XIX ст. уже охоплюють ширше коло синтаксичних проблем, проте на чільному місці залишається висвітлення синтаксичного зв'язку між словами. У ХХ ст. питання про синтаксичні зв'язки виходить за межі наукових і дидактичних граматик, йому починають присвячувати спеціальні розвідки й монографії. Усе це сприяло тому, що синтаксичну теорію було значно розширено відкриттям нових типів і форм синтаксичного зв'язку та поглиблено уточненнями особливостей та умов реалізації уже відомих типів і форм цього феномену. Поповнення арсеналу різновидів синтаксичного зв'язку та занурення в його природу з нових методологійних позицій неминуче стимулювали класифікаційні пошуки 
в цій галузі. На сьогодні запропоновано кілька класифікацій, укладених за різними принципами (ПриятКИНА 1968, ЗолотовА 1973, ВиховАНЕЦь 1993, ЗАГнітко 2004, Мірченко 2004). Але в граматичній системі слов'янських мов, зокрема української, функціюють і такі різновиди синтаксичного зв'язку, які поки що неможливо вмістити в жодні класифікаційні схеми, - як, наприклад, недиференційований, приєднувальний чи подвійний зв'язки.

Особливу цікавість у цьому контексті становить подвійний синтаксичний зв’ язок, природа якого не відповідає жодній з опозиційних ознак синтаксичного зв'язку на осі закритості/відкритості. Цей зв' язок не можна вважати закритим, оскільки, застосовуючи його один раз, ми поєднуємо не два, а три компоненти водночас; і він не є відкритим, оскільки кількість поєднуваних ним компонентів не є нескінченною (як у випадку відкритого різновиду сурядного зв'язку), а чітко окресленою - три. Проблема специфіки цього синтаксичного зв'язку постала ще на початку XX ст., однак вона й досі остаточно не розв'язана. Це зумовлено як складністю самого явища, так і суб'єктивними чинниками, які полягають у тому, що різні лінгвісти вбачали реалізацію цього зв'язку в різних конструкціях і по-різному інтерпретували механізм його встановлення й форми реалізації. Але подальше заглиблення в граматичну сутність цього феномену та його адекватна кваліфікація неможливі без опису обсягу цього поняття.

3 огляду на це мета нашої розвідки - 3'ясувати умови зародження ідеї про подвійний синтаксичний зв'язок та простежити еволюцію потрактування цього явища. Зауважимо, що до аналізу залучені джерела як українських науковців, так і російських, адже 3 відомих історичних причин тривалий час українська лінгвістика розвивалася у взаємодії з російською.

Уперше на ідею про пов’язаність одного члена речення одночасно з двома іншими натрапляємо в праці Д. Овсянико-Куликовського «Керівництво до вивчення синтаксису російської мови». Науковець поряд зі складеними присудками виокремив ще й подвійні присудки, які відрізняються від складених тим, що репрезентовані сполукою дієслова (здебільшого зі значенням волевиявлення) та інфінітива, які називають дії різних осіб, напр.: «Прошу вас приитти до мене завтра; Він доручив адвокату подати позов» (ОвсяникоКуликовский 1907: 88). Специфікою таких присудків, на переконання Д. Овсянико-Куликовського, є те, що «присудковість, виражена цими двома дієсловами, розділяється на дві частини, з яких одна стосується одного підмета, а інша - іншого» (Овсянико-Куликовский 1907: 88). У такий спосіб лінгвіст констатував подвійний зв'язок присудків такого зразка з підметом, який указує на суб'єкта волевиявлення, з одного боку, та 3 додатком, який передає значення адресата волевиявлення (і який дослідник інтерпретує другим підметом), з іншого боку, напр.: Прошу вас прийти до мене завтра: прошу + прийти - ви.

Номінацією «подвійний присудок» оперував і О. Шахматов, але він наполягав на його вживанні замість терміна «складений присудок». На думку академіка, у випадках «з так званим складеним присудком ми маємо справу 
3 поєднанням двох присудків, з подвійним присудком: один 3 них дієслівний, інший ад'єктивний або іменний» (ШАХмАТОв 2011: 44). Такий подвійний присудок охоплює три лексико-граматичні різновиди: 1) 3 першою частиною, вираженою дієсловом быть 3 «його блідим реальним змістом»; 2) 3 першою частиною, представленою іншими дієсловами 3 «менш блідим змістом»; 3) 3 першою частиною, репрезентованою дієсловами «повного змісту». Учений проілюстрував прикладами лише цей тип: он сидит мрачен, он пал мертвый, он пришел пьяный (ШАХмАТов 2011: 44-45). Мовознавець наголосив на реалізації подвійного синтаксичного зв'язку в таких реченнях, адже обидва ці присудки одночасно узгоджуються 3 підметом (ШАХмАтов 2011: 44-45).

О. Пєшковський третій 3 окреслених різновидів потрактовував особливим типом присудків, який вирізняється 3-поміж інших тим, що його дієслівний компонент має «речове значення» на відміну від граматикалізованої одиниці бути і под. (ПЕшковский 2001: 249-250). Лінгвіст не заперечував подвійного синтаксичного зв'язку між таким присудком і підметом, проте витлумачував його як динамічне, а не статичне, явище. Учений підкреслював, що виникнення подвійного синтаксичного зв'язку в зазначених конструкціях є наслідком «величезного синтаксичного зсуву», який полягає в тому, що «прикметник залишає свою нормальну точку опори - іменник - і зчіплюється 3 дієсловом» (ПЕшковский 2001: 250).

Питання про подвійний синтаксичний зв' язок порушено й у колективній праці «Підвищений курс української мови» (1931) за редакцією Л. Булаховського. Попри те, що подвійний присудок у цьому виданні також розглянуто в межах складених («зложених») присудків як аналогійний складеному іменному, тут уперше адекватно кваліфіковано сутність його синтаксичного зв' язку з підметом. М. Перегінець, автор відповідного розділу, схарактеризував механізм реалізації цього феномену, який полягає у тому, що «присудкові прикметники виявляють одночасно двійне тяжіння до допоміжного дієслова та підмета» (ПЕРеГінець 1931: 250). Свідченням цього є формальне узгодження прикметника 3 підметом та його паралельний зв'язок 3 дієсловом, який цементує їх у цілісну значеннєву одиницю (ПЕРеГІнЕць 1931: 250), напр.: «Під його враженням Максим стояв приголомшений посеред хаосу» (І. Багряний).

У пізнішій подібній праці за редакцією Л. Булаховського, напевне, під впливом ідей О. Пєшковського вже не наголошено на подвійному зв'язкові прикметника з іменником-підметом та дієсловом, а констатовано лише його залежність від дієслова. Але на позначення цього зв'язку введено спеціальний термін - «тяжіння», який визначено як «граматичну пару з дієслова і прикметника (дієприкметника або займенника-прикметника), узгоджуваного з першим у числі та роді; із смислового боку цей зв' язок означає, яким є предметпідмет у момент здійснення приписуваної йому присудком дії» (БулАховСький 1951: 15). Відтоді термін «тяжіння» увійшов до активного лінгвістичного обігу (ГРЯ 1954: 25-26, ФИНКЕЛЬ-БАЖЕНОВ 1965: 494, КУЛИК 1965: 19, АхмановА 1966: 481, ХАСАновА 1981). Оскільки авторство розділів у названому виданні не зазначено, творцем цього терміна вважають Л. Булаховського. 
Проте, на нашу думку, винайдення цієї номінації справедливо пов'язувати 3 ім'ям М. Перегінця, адже саме він у розділі «Синтакса простого речення» праці «Підвищений курс української мови» (1931) визначає граматичну поведінку ад'єктивів у реченнях 3 подвійним присудком лексемою «тяжіння», не надаючи їй терміноголійного статусу. Варто зазначити, що до сьогодні змістове наповнення цього терміна в різних мовознавців дещо різниться: одні науковці використовують його в значенні, наведеному в «Курсі сучасної української літературної мови» (1951), інші - вживають власне як синонім до позначення «подвійний синтаксичний зв' язок» і визначають ним комплексний зв' язок трьох компонентів у конструкціях формально-структурної моделі $\mathrm{S}_{1}+\mathrm{V}_{\mathrm{f}}+\mathrm{Adj}_{1,5}$. Але тут ми не зупинятимемося на цій проблемі, оскільки вона вже поставала предметом окремої розвідки (Коьченко 2016).

3 середини XX ст., після виходу вищезазначеної праці, поняття подвійного синтаксичного зв'язку певним чином усталилося. У мовознавстві запанувала думка про те, що сферою його реалізації є побудови формально-структурної моделі $\mathrm{S}_{1}+\mathrm{V}_{\mathrm{f}}+\mathrm{Adj}_{1,5}$, i почалися активні дослідження цих конструкцій. Відкриття нового різновиду синтаксичного зв'язку українські й російські мовознавці сприйняли як заповнення однієї з лакун теоретичного синтаксичну, тому закономірно, що відомості про це явище відбилися в підручниках для вишів (ФИНКЕЛЬ-БАЖЕНОВ 1965: 493-494, Кулик 1965: 19-20) та навіть академічних граматиках (ГРЯ 1954: 25-26, СУЛМ 1972: 175-176). Щоправда, потрактування граматичного статусу цього явища в деяких авторів дещо відрізнялося від визначення, поданого у «Курсі сучасної української літературної мови» за редакцією Л. Булаховського. Зокрема, М. Баженов вважає, що тяжіння є різновидом прилягання, оскільки дієслово й прикметник чи його еквівалент поєднані на грунті змістового зв'язку за відсутності формальних показників підпорядкування одного компонента іншому (ФИНКЕЛЬ-БАЖЕНОВ 1965: 493-494). Натомість Б. Кулик тяжінням називає не безпосередній зв’язок дієслова й ад'єктива, а комплексний зв'язок трьох елементів формальноструктурної моделі $\mathrm{S}_{1}+\mathrm{V}_{\mathrm{f}}+\mathrm{Adj}_{1,5}$. Учений, розглядаючи тяжіння як форму підрядного зв'язку, не протиставляє його всім іншим формам, а потрактовує своєрідним синтезом двох інших - узгодження й прилягання. Як аргументує науковець, «форма прикметника (дієприкметника і т. п.) тяжить до присудка (прилягає, бо форма підпорядкованого дієслова не визначається дієсловом); разом $з$ тим прикметник (дієприкметник і т. п.) тяжить і до підмета» (Кулик 1965: 19-20).

Помітне місце в цій галузі посіли ідеї I. Распопова, який продовжив студіювання подвійного синтаксичного зв'язку в напрямі, окресленому М. Перегінцем. Він терміном «тяжіння» визначає зв'язок між трьома елементами підметом і складниками подвійного присудка й тлумачить його як «такий різновид підрядного зв'язку, який виражає семантично зумовлене намагання одного $з$ компонентів синтаксичної конструкції співвіднести своє наповнення з іншим компонентом за посередництва третього компонента, з яким вони обидва також перебувають в певному зв'язку» (РАспопов 1970: 40). За 
I. Распоповим специфіка подвійного зв'язку полягає в синтезі координації та субординації, пор.: «Роман вийшов зажурений» (Б. Грінченко) - Роман вийшов (координація) + вийшов зажурений (субординація). Окрім цього, I. Распопов розширює сферу функціювання подвійного синтаксичного зв'язку, залучаючи сюди речення з суб'єктним і об'єктним інфінітивами (Він обіияв мені приїхати; Він наказав мені йти) та речення з дієприслівниками (Проїжджаючи повз станиію, я задивився у вікно й загубив капелюха) (РАспоПов 1970: 38-39). На думку лінгвіста, суб'єктний інфінітив пов'язаний з присудком і водночас за його посередництва 3 підметом, а об'єктний інфінітив - теж 3 присудком і за його посередництва 3 додатком. Таку позицію можна вважати продовженням ідеї Д. Овсянико-Куликовського, який, як було зазначено вище, подвійний зв'язок вбачав лише в реченнях з об'єктним інфінітивом. Щодо конструкцій $з$ дієприслівниками, то І. Распопов констатує тут наявність подвійного синтаксичного зв 'язку, який реалізується тільки між трійкою компонентів «субстантив-підмет - дієслово-присудок - дієприслівник». Сутність цього явища полягає в тому, що дієприслівник підпорядковується дієслову та за його посередництва «специфічно» повзв'язується з субстантивом (РАСПоПов 1970: 38).

Дещо переосмислює термін «тяжіння» 3. Силкіна, оперуючи ним на позначення зв'язку ад'єктива з субстантивом-підметом (СилкинА 1973). Однак, як зазначає дослідниця, цей зв'язок не може зреалізуватися безпосередньо між ад'єктивом і субстантивом, а виникає лише в складі тричленної конструкції і лише за посередництва третього компонента - дієслова-присудка (СилкинА 1973: 3-4). Це дало їй підстави визначити характер подвійного синтаксичного зв'язку в конструкціях формально-структурної моделі $\mathrm{S}_{1}+\mathrm{V}_{\mathrm{f}}+$ $\operatorname{Adj}_{1,5}$ як опосередкований. Особливим внеском 3. Силкіної у теорію синтаксичних зв'язків можна вважати те, що вона детально описала ще одну сферу реалізації подвійного зв'язку, а саме - конструкції формально-структурної моделі $\mathrm{V}_{\mathrm{f}}+\mathrm{S}_{4}+\mathrm{Adj}_{4,5}$, напр.: «Його вели закутого в ланцюги...» (Ю. Винничук). Специфіка подвійного синтаксичного зв'язку в таких побудовах полягає в тому, що тут він не поширюється на весь предикативний центр: ад'єктив, перебуваючи з субстантивом-додатком у предикативному зв'язку, за посередництва цього субстантива теж залучається до підпорядкування опорному дієслову (Силкина 1973: 12).

Проблемі подвійного синтаксичного зв'язку присвятила низку праць Л. Д. Чеснокова (Чеснокова 1972, Чеснокова 1980). Насамперед вона зосередила дослідницьку увагу на його реалізації у структурах двох моделей $\mathrm{S}_{1}+\mathrm{V}_{\mathrm{f}}+\operatorname{Adj}_{1,5}$ та $\mathrm{V}_{\mathrm{f}}+\mathrm{S}_{4}+\mathrm{Adj}_{4,5}$ - за іiі визначенням, «у реченнях 3 дієслівноіменним означувачем». Л. Чеснокова долучається до кола вчених, які наголошують на функціюванні в таких конструкціях комплексного синтаксичного зв'язку між трьома компонентами водночас. Ад'єктив у побудовах такого зразка «однією частиною своїх граматичних категорій розкриває залежність від одного слова, іншою частиною граматичних категорій - від іншого» (ЧесноковА 1972: 51). Погляд на цей феномен крізь призму граматичної суб- 
ординації уможливив дійти висновку про те, що прикметник чи його еквівалент сполучається 3 іменником підрядним зв'язком у формі узгодження, а 3 дієсловом - підрядним зв'язком у формі керування або прилягання. У разі вираження ад'єктива орудним відмінком підпорядкування субстантивові відбувається у формі неповного узгодження (немає узгодження у відмінку), а вербативові - у формі керування (ЧЕсноковА 1972: 54), напр.: «Дісталися вони пагорба стомленими...» (І. Багряний). У разі ж представлення ад'єктива називним відмінком його зв'язок з субстантивом утілений у повному узгодженні (ЧЕсноковА 1972: 55), а з вербативом - «виявляється схожим на прилягання», бо залежний компонент - ад'єктив - має форми словозміни, але в його підпорядкуванні вербативу вони не беруть участі (ЧЕсноковА 1972: 56), напр.: «Рута знесилена лягла на траву і дивилася в небо...» (Ю. Винничук). У пізнішій праці Л. Чеснокова (ЧЕсноковА 1980), спираючись на власні дослідження та враховуючи напрацювання попередників, виокремлює п'ять типів конструкцій, у яких функціює подвійний синтаксичний зв'язок: 1) конструкції формально-структурних моделей $\mathrm{S}_{1}+\mathrm{V}_{\mathrm{f}}+\mathrm{Adj}_{1,5}$ та $\mathrm{V}_{\mathrm{f}}+\mathrm{S}_{4}+\mathrm{Adj}_{4,5}$, напр.: «Каспер повернувся похмурий і натомлений» (Ю. Винничук); «...ти хочеш бачити світ чистим і неспотвореним, чесним і справедливим» (Ю. Винничук); 2) побудови з суб'єктним та об'єктним інфінітивом, напр.: «Свгеній обіияв зайнятися сею справою і попрощався з Вагманом» (І. Франко); «Я запросив їх сісти і вгостив вином» (Ю. Винничук); 3) речення 3 дієприслівниками, напр.: «Рута постукала в двері і, не чекаючи на кректання старої, увійшла» (Ю. Винничук); 4) структури з відокремленими означеннями, які мають обставинні семантичні нашарування, напр.: «Бояри ж, не навиклі до таких неприступних і карколомних доріг, пішли здовж валу» (І. Франко); 5) речення 3 означеннями, які узгоджуються 3 підметом і водночас у змістовому плані тяжіють до дієслова, зумовлюючи реалізацію обставинних семантико-синтаксичних відношень, напр.: «Голому розбій не страшний» (М. Вовчок) $\leftarrow$ Людині розбій не страшний, якщо вона гола.

О. Каминіна обгрунтувала напівпредикативну природу подвійного синтаксичного зв’язку. Випрацьовуючи теорію напівпредикативності, лінгвіст показала, що формально-граматичний вияв цього явища саме й полягає в реалізації подвійного синтаксичного зв'язку між трьома компонентами. Організаційним центром цієї «трійки» є субстантив-підмет, з яким напівпредикативний член перебуває у «певному синтаксичному зв'язкові» (КАмынинА 1974: 14-15). Водночас цей напівпредикативний член не може бути ізольованим від дієслова-присудка, оскільки саме присудок локалізує в часовій площині виражену ним ознаку (КАмынинА 1974: 30). Проаналізувавши випадки реалізації такого синтаксичного зв'язку, О. Каминіна виокремлює три групи напівпредикативних конструкцій (КАмынинА 1974: 47): 1) речення $з$ дієприкметниковим або дієприслівниковим зворотом, напр.: «Це був величезний старий орел, злинялий від сония й негоди» (О. Донченко); «Човен, набираючи uвидкість, боком пішов на перекат» (Г. Тютюнник); 2) побудови формальноструктурної моделі $\mathrm{S}_{1}+\mathrm{V}_{\mathrm{f}}+\mathrm{Adj}_{1,5}$ та речення з відокремленим непоширеним 
означенням, напр.: «...але тут, на помості, він стояв геть безпорадний...» (Ю. Винничук); «Іде чумак з-за лиману з чужим добром, безталанний...» (Т. Шевченко); 3) речення $з$ прийменниково-відмінковими комплексами, які виражають мотиваційне значення стосовно предикативного центру, напр.: «Сумні без батька двоє діток цих» (М. Вінграновський).

Прикметно, що в цей час ідея про існування подвійного синтаксичного зв’ язку була настільки популярною в граматичній теорії, що подекуди до сфери функціювання цього явища зараховували навіть такі конструкції, у яких його реалізація видається сумнівною. Приміром, Н. Валгіна прийменникововідмінкові комплекси, для яких у межах речення неможливо встановити опорний компонент, потрактовує підпорядкованими двом синтаксичним домінантам водночас - дієслову та іменникові (ВАлгинА 1972), напр.: «Стали вертатись поранені з Павлівки» (Ю. Яновський). Дослідниця пояснює, що виникнення подвійного зв'язку в таких реченнях пов'язане із розпадом дієслівної сполуки внаслідок синтаксичного переміщення прийменниково-відмінкової форми. Такі прийменниково-відмінкові комплекси або починають залежати від іменника, або посідають позицію члена, який пояснює усю реченнєву конструкцію (ВАлгинА 1972: 100-101), напр.: «Що казав цей чоловік людям на березі ставка?» (В. Винниченко). Аналогійну позицію обстоюють й інші лінгвісти. Зокрема, Л. Пастухова до сфери поширення подвійного синтаксичного зв'язку, окрім конструкцій формально-структурної моделі $\mathrm{S}_{1}+$ $\mathrm{V}_{\mathrm{f}}+\mathrm{Adj}_{1,5}$, зараховує $\mathrm{i}$ компоненти 3 синкретичною семантикою, яка зумовлена неможливістю однозначного встановлення щодо них опорного компонента (ПАстуховА 1972). На нашу думку, синкретичними в семантичному плані подібні одиниці постають лише в межах одного речення, а із залученням контексту або позамовної ситуації їхнє значення постає цілком очевидним, бо в такому разі стає зрозумілим, від якого саме компонента вони залежать (див. про це КоБченко 2007). 3 огляду на це не бачимо достатньо підстав кваліфікувати прийменниково-відмінкові комплекси такого зразка підпорядкованими двом синтаксичним домінантам водночас. Стосовно цього вважаємо слушною думку Л. Чеснокової, яка описані побудови зараховує до явищ синтаксичної омонімії (ЧесноковА 1980: 69), адже у таких випадках залежний компонент потенційно може бути підпорядкованим двом синтаксичним домінантам, але в кожному конкретному контексті реалізується лише одна 3 його потенційних залежностей.

Дещо суперечливою щодо цього питання видається позиція В. Кононенка. 3 одного боку, він констатує наявність подвійного синтаксичного зв'язку у конструкціях, де один компонент потенційно може бути залежним від двох інших (Кононенко 1975: 31-36). А з іншого боку, лінгвіст зазначає, що подвійній синтаксичний зв'язок треба відрізняти від «несправжнього (фіктивного)» зв'язку певного члена 3 двома опорними компонентами (Кононенко 1975: 38). Далі мовознавець зазначає про випадки синтаксичної омонімії та доцільність залучення контексту для адекватного потрактування сумнівної одиниці. Така думка нам цілком імпонує, однак у праці В. Кононенка зали- 
шаються нез'ясованими критерії диференціації відмінкових і прийменникововідмінкових форм, які вступають у «справжній» подвійний зв'язок 3 двома іншими компонентами, та відмінкових і прийменниково-відмінкових форм, які є фактами синтаксичної омонімії.

Незважаючи на це, аналізована розвідка В. Кононенка є цінним внеском у теоретичний синтаксис, адже тут уперше відбито наукові рефлексії щодо реалізації подвійного зв'язку на рівні складного речення. Лінгвіст обгрунтував, що підрядна предикативна частина, яка приєднана до субстантива головної за допомогою сполучних слів де, куди, звідки, коли тощо, залежить і від цього субстантива, і від присудка головної частини, напр.: «А під кручею, де розмістилась його вогнева позиція, діялося щось незвичайне...» (О. Гончар) (КононЕнко 1975: 41). У таких випадках трикомпонентна конструкція, у якій реалізується подвійний зв'язок, складається з іменника, дієслова та підрядної предикативної частини (Кононенко 1975: 41). Пізніше цю ідею розвинула Р. Христіанінова, назвавши цей зв' язок підрядним опосередкованим (ХРистіАнІновА 2012: 141-144).

У 80-х pp. ХХ ст. інтерес науковців до проблеми подвійного синтаксичного зв’язку не згас, напрацювання в цій галузі продовжилися: окрім згаданої книги Л. Чеснокової, протягом цього часу з'являються статті та дисертаційні праці. Відомі спроби лінгвістів розвинути теорію «синтаксичного зсуву» О. Пєшковського. Згідно з цією концепцією подвійний синтаксичний зв'язок у конструкціях формально-структурної моделі $\mathrm{S}_{1}+\mathrm{V}_{\mathrm{f}}+\mathrm{Adj}_{1,5} \mathrm{P}$. Хасанова інтерпретує як перехідне явище, оскільки прикметник «не порвав до кінця своїх синтаксичних відношень $з$ підметом і через це не закріпився цілком за дієслівним присудком» (ХАСАновА 1981: 8). На переконання дослідниці, перехідність цього синтаксичного зв'язку зумовлена «деградацією одного зв'язку» (з підметом) та «прогресом іншого» (з дієслівним компонентом присудка) (ХАСАНОВА 1981: 8). Остаточний же розрив зв'язку прикметника з іменникомпідметом та його підпорядкування дієслову відбуваються в конструкціях, де прикметник виражений формою орудного відмінка (ХАСАноВА 1981: 9), напр.: Вони прийшли останніми (С. Жадан). Проте така аргументація видається непереконливою $з$ двох причин: по-перше, морфологійна форма ад'єктива (число й рід) зумовлена не дієсловом, а відповідною морфологійною формою іменника-підмета; по-друге, інструменталь є спеціалізованим засобом вираження іменної частини складеного іменного присудка, і тому форма орудного відмінка ад'єктива не віддаляє його від підмета, а, навпаки, засвідчує реалізацію предикативного зв'язку між ними.

Р. Кузмінська, досліджуючи випадки формально вираженої подвійної залежності компонентів у російській та польській мовах, виокремлює дві сфери iii реалізації - прості речення формально-структурної моделі $\mathrm{S}_{1}+\mathrm{V}_{\mathrm{f}}+\mathrm{Adj}_{1,5}$ та складнопідрядні з підрядною означальною предикативною частиною, яка поєднується з головною сполучним словом який, напр.: «Найжахливіша пригода, яку пережив Каспер, трапилася з чорнокнижником...» (Ю. Винничук) (КузьминьскА 1981: 7). Ад’єктив у реченнях формально-структурної моделі 
$\mathrm{S}_{1}+\mathrm{V}_{\mathrm{f}}+\mathrm{Adj}_{1,5}$ учена інтерпретує як аргумент предиката, тому називає «копредикативним членом», а форму його зв'язку з предикатом визначає як «копредикативну» (КузьминьскА 1981: 6). А підпорядкування сполучного слова який опорному компонентові головної предикативної частини вона кваліфікує як «коатрибутивний» (КузьминьскА 1981: 6).

Попри окреслену кількість досліджень подвійного синтаксичного зв'язку його граматична природа залишається до кінця не з'ясованою. Саме тому й на межі тисячоліть лінгвісти не втрачають цікавості до цієї теоретичної проблеми, намагаючись іiї розв'язати з позицій функційної граматики. Зокрема, I. Вихованець ад'єктив у конструкціях формально-структурної моделі $\mathrm{S}_{1}+\mathrm{V}_{\mathrm{f}}+\mathrm{Adj}_{1,5}$ кваліфікує компонентом подвійного присудка й аргументує, що подвійність синтаксичного зв'язку в таких побудовах зумовлена не підпорядкуванням цього ад'єктива відразу двом синтаксичним домінантам, а специфікою предикативного поєднання іменника-підмета з обома компонентами подвійного присудка. Застосовуючи комплексний аналіз на формальнограматичному й семантико-синтаксичному рівнях та прийоми дериваційного аналізу, він довів, що в конструкціях такого зразка внаслідок об'єднання двох елементарних речень зі спільним підметом відбувається накладання двох предикативних зв'язків (ВиховАнЕць 1992: 89), напр.: «Амалія натомість стояла штивна, наче статуя Мелюзини на Ринку» (Ю. Винничук) $\leftarrow$ Амалія стояла + Амалія була штивна. Дещо складнішими є дериваційні перетворення в конструкціях формально-структурної моделі $\mathrm{V}_{\mathrm{f}}+\mathrm{S}_{4}+\mathrm{Adj}_{4,5}$. Це результат об'єднання двох елементарних побудов, об'єкт спрямування дії одного з вихідних речень $є$ суб' єктом стану другого вихідного речення (ВиховАнЕць 1992: 2829), напр.: «Я пам'ятаю батька не старим» (Л. Костенко) $\leftarrow$ Я пам'ятаю батька + Батько був не старим. У похідній конструкції іменник залежить від дієслова, а оскільки прикметник чи його еквівалент перебуває з цим іменником у взаємозумовленому зв'язкові, він також підпорядковується дієслову.

3'ясовуючи функції відмінків української мови, І. Вихованець дещо поіншому окреслив механізм встановлення синтаксичного зв'язку в структурах з інфінітивом і дативом. Давальний відмінок, містячись у валентній рамці дієслова із семантикою заборони, наказу, дозволу тощо, одночасно потрапляє в залежність і до підпорядкованого цьому дієслову інфінітива, напр.: «Наказав провіднииі прибрати, і на підлозі з'явився новенький хідник...» (В. Речмедін) (ВиховАнець 2004: 74). У такий спосіб датив у конструкціях такого зразка опиняється у подвійній синтаксичній залежності.

Також мовознавець виявив ще одну досі не описану сферу функціювання подвійного синтаксичного зв'язку, а саме - конструкції з давальним відмінком адресатно-посесивної семантики (Вихованець 1987: 117), напр.: «Бризки хвиль вдарили їй в обличчя... (Ю. Винничук). Давальний відмінок iз адресатно-посесивним значенням був об'єктом наукового інтересу й до цього часу, проте на особливості його синтаксичних зв'язків з іншими компонентами речення вперше звернув увагу I. Вихованець. Він аргументував, що після об’єднання двох семантично елементарних речень та згортання 
в одному з них предиката належності давальний, який позначає суб'єкта володіння, сполучається підрядним зв'язком з компонентом у функції об' єкта володіння, який водночас $є$ й об’єктом спрямування активної дії в другому реченні, пор.: «Кінь вороний у дальню путь не хоче, І срібним порохом Чумацького шляху Засліплює мандрівникові очі» (Ю. Дараган) $\leftarrow$ Кінь засліплює очі + Очі належать мандрівникові. Підпорядкування давального адресатнопосесивного, окрім іменника, ще й дієслову відбувається через те, що сильна спрямованість дії на предмет втягує у свою орбіту й суб'єкт володіння цим предметом (ВиховАНЕць 1987: 117). Безпосередній зв'язок об'єкта володіння 3 опорним дієсловом зумовлює опосередкований підрядний зв'язок з ним суб'єкта володіння, тому датив у таких конструкціях залежіть і від дієслова, і від іменника (ВихОВАНЕЦь 1987: 118).

Заглибившись в особливості реалізації підрядного зв'язку в конструкціях різних структурних типів, І. Вихованець 3'ясував, що поряд з його прислівним та детермінантним різновидпми можливий ще й опосередкований вияв. Опосередкований підрядний зв'язок функціює між двома компонентами, якщо залежний підпорядковується опорному за посередництва третього компонента (ВиховАнЕць 1992: 28), напр.: «Там, на столі, лежить моє перо» (Л. Костенко) - компонент на столі є уточнювальним щодо компонента там і за його посередництва пов'язаний з компонентом лежить. Оскільки опосередкований підрядний зв'язок не є сумою двох інших зв'язків, а реалізується між трьома компонентами водночас, є всі підстави кваліфікувати його подвійним. 3 огляду на це можна говорити про розширення сфери подвійного синтаксичного зв’язку завдяки опосередкованому підрядному.

Складність самого явища подвійного зв'язку та дискусії мовознавців щодо його потрактування стимулювали подальші пошуки в цій галузі. Приміром, Л. Томусяк, розвиваючи ідеї І. Распопова та I. Вихованця, дослідила формально-граматичну, семантико-синтаксичну та комунікативну організацію речень формально-структурних моделей $\mathrm{S}_{1}+\mathrm{V}_{\mathrm{f}}+\mathrm{Adj}_{1,5} \mathrm{Ta} \mathrm{V}_{\mathrm{f}}+\mathrm{S}_{4}+\mathrm{Adj}_{4,5}$ (Томусяк 1999). Аналіз цих конструкцій на формально-граматичному рівні наштовхнув учену на висновок про те, що одночасна пов'язаність ад'єктива 3 іменем та дієсловом зумовлюють виникнення особливого синтаксичного зв'язку - тяжіння (Томусяк 1999: 22). Мовознавець довела, що в організації подвійного зв'язку в зазначених конструкціях особлива роль належить саме дієслову, адже воно виконує «посередницьку» роль у поєднанні субстантива й ад’єктива (Томусяк 1999: 25-26). Цінним для осягнення граматичної природи подвійного синтаксичного зв'язку є спостереження Л. Томусяк, що він реалізується тільки в побудовах $з$ повнозначними дієсловами, які не десемантизувалися, тоді як у побудовах з дієслівними власне-зв'язками або контекстуальними зв'язками він не можливий (Томусяк 1999: 27), пор.: «Іола теж їхав невеселий» (Г. Копань) - «Чого ти сьогодні такий невеселий був?» (Панас Мирний).

На студіюванні ще одного різновиду подвійного синтаксичного зв' язку, а саме - на напівпредикативному, зосередила увагу О. Кульбабська, системно 
описавши функційну специфіку речень з дієприслівниковими зворотами (див. КульБАБСьКА 1998). Подвійний синтаксичний зв'язок у таких конструкціях зумовлений граматичним статусом дієприслівника, який «співвідноситься семантично й граматично з присудком, але й виявляє семантичне тяжіння до підмета» (КульБАБсьКА 1998: 37). Розчленувати цей зв'язок на два бінарні неможливо, оскільки «предикативність дієприслівника завжди залежна, опосередкована зв'язком із присудком, і тому не сприймається поза основною лінією речення» (КульБАБСьКА 1998: 38).

Останні дослідження в галузі синтаксичних зв'язків свідчать про розширення сфери функціювання опосередкованого підрядного зв'язку. Р. Христіанінова довела, що йому властива різнорівневість функціювання: він реалізується не лише у формально простому реченні між компонентами одного рівня - словоформами, а й у складному реченні між компонентами різних рівнів - словоформами та предикативними частинами (ХристіАніновА 2012: 141-144). Цей зв’язок функціює в побудовах, де підрядна частина підпорядкована певному компонентові головної частини, і за його посередництва співвіднесена 3 предикативним ядром головної частини або входить до валентної рамки предиката головної частини (ХристіАнгновА 2012: 141-144), напр.: «Над ранок, коли крізь нічну чорноту починають пробиватися синьо-фіалкові кольори, все закінчується» (А. Дністровий); «Далеко внизу, де починалась долина, паслася кабарга» (О. Донченко).

Також Р. Христіанінова обгрунтувала доцільність виокремлення ще однієї моделі подвійного присудка - такого, який формують два повнозначні дієслова однакової форми (зазвичай теперішнього або минулого часу недоконаного виду), що позначають одночасні дії, напр.: «Я теж сидів читав, потім вийшов за цигарками» (О. Гончар) (ХристіАнгновА 2015: 244). Твердження дослідниці про те, що граматична природа таких конструкцій ідентична природі присудка, утвореного поєднанням повнозначного дієслова й ад'єктива, видається переконливим. Отже, є підстави говорити про реалізацію подвійного синтаксичного зв'язку і між компонентами конструкцій формально-структурної моделі $\mathrm{S}_{1}+\mathrm{V}_{\mathrm{f}}+\mathrm{V}_{\mathrm{f}}$, пор.: Він стоїть слухає $\leftarrow$ Він стоїть + Він слухає.

I. Попова, пропонуючи свою концепцію синтаксичних зв'язків, де передбачено поділ на дві групи - системні й позасистемні, розглядає подвійний зв'язок у межах останньої групи. На позначення цього явища вона оперує терміном розчленування й виокремлює кілька сфер його реалізації: 1) конструкції формально-структурних моделей $\mathrm{S}_{1}+\mathrm{V}_{\mathrm{f}}+\mathrm{Adj}_{1,5}$ та $\mathrm{V}_{\mathrm{f}}+\mathrm{S}_{4}+\mathrm{Adj}_{4,5}$; 2) речення зі складним підметом, що має семантику вибірковості, напр.: «Один із наших студентів не повернувся до університету після зимових канікул»; 3) складносурядні й складнопідрядні структури із співвідносними лексичними компонентами в обох частинах, напр.: «До мене приїхала моя сестра, яку я не бачив три роки; Мій друг приніс мені дуже ефективні ліки, i завдяки їм я швидко видужав)» (ПоповА 2009: 267).

Отже, поняття подвійного синтаксичного зв'язку визначає не одиничне явище, а охоплює цілу низку явищ. Це тип, що об'єднує різновиди синтак- 
сичного зв’ язку на грунті їхніх спільних ознак: тричленність конструкції та комплексність розгортання зв'язку. Особливістю такої тричленної побудови $\epsilon$ те, що із вилученням одного $з$ компонентів, вона руйнується. А сутність комплексності полягає в тому, що кожен 3 трьох компонентів перебуває у синтаксичному зв' язку з двома іншими. Як показав аналітичний огляд наукових джерел, мовознавці виокремлюють такі сфери функціювання подвійного синтаксичного зв'язку: 1) речення формально-структурної моделі $\mathrm{S}_{1}+$ формально-структурної моделі $\mathrm{V}_{\mathrm{f}}+\mathrm{S}_{4}+\mathrm{Adj}_{4,5}$; 4) речення 3 об'єктним або суб'єктним інфінітивом; 5) речення 3 дієприслівником або дієприслівниковим зворотом; 6) речення 3 прикметниковим або дієприкметниковим зворотом; 7) речення 3 давальним відмінком адресатно-посесивної семантики; 8) речення $з$ уточнювальними прикладками й обставинами; 9) складнопідрядні речення $з$ підрядною означальною, приєднаною сполучним словом який; 10) складнопідрядні речення, у яких підрядна частина приєднується сполучними словами де, куди, коли тощо до компонента 3 адвербіальною семантикою головної та за посередництва цього компонента до всієї головної; 11) речення зі складним підметом, що має семантику вибірковості. Треба зауважити, що, з одного боку, цей перелік не є вичерпним, адже охоплює лише найтиповіші вияви аналізованого явища, а $з$ іншого боку, виокремлення деяких з перерахованих сфер залишається дискусійним і ще потребує наукових рефлексій. Подальші дослідження й опис специфіки конструкцій 3 подвійним синтаксичним зв'язком сприятимуть теоретичному осмисленню цього феномену та створенню цілісного вчення про синтаксичні зв'язки.

\section{Література}

АХмАнова $1966=$ АХмановА О. С. Словарь лингвистических терминов. Москва, 1966. БУЛАХОВСьКИй 1951 = БуЛАХОвСьКИй Л. А. (ред.) Курс сучасної украӥнської літературної мови. Т. 2. Синтаксис. Київ, 1951.

ВАЛГИНА 1972 = ВАЛГИНА Н. С. О двусторонней синтаксической связи в современном русском языке. Русский язык в школе 1972/5: 99-104.

ВИХОВАНЕЦь 1987 = ВИХОВАНЕЦь І. Р. Система відмінків украӥнської мови. Київ, 1987. ВИХОВАНЕЦЬ 1992 = ВИХОВАНЕЦЬ І. Р. Нариси з функиіонального синтаксису української мови. Київ, 1992.

ВиХОВАНЕЦь 1993 = ВиХОВАНЕЦЬ І. Р. Граматика української мови. Синтаксис. Київ, 1993.

ВИХОВАНЕЦЬ 2004 = ВИХОВАНЕЦЬ І., ГОРОДЕНСЬКА К. Теоретична морфологія украӥнської мови. Київ, 2004.

ГРЯ 1954 = Грамматика русского языка. Т. 2. Синтаксис. Ч. 1. Москва, 1954.

ЗАГнітко 2004 = ЗАГнгтко А. П. Синтаксичні зв'язки у внутрішній структурі українського простого речення. Донецький вісник Наукового товариства ім. Шевченка. Т. 5. Донецьк, 2004. 144-152.

ЗолотовА 1973 = ЗолотовА Г. А. Очерк функиионального синтаксиса русского языка. Москва, 1973.

КАмЫнинА 1974 = КАмЫнинА А. А. О полупредикативных конструкциях в простом предложении. Москва, 1974. 
КОБЧЕнко 2007 = КоБченко Н. В. Контекст як критерій диференціації слабкого керування й вільного поєднання у відмінковому вияві. В кн.: Имя и слово. Mатериаль международной научной конференции. Ч. 1. Брест, 2007. 208-211.

КоБченко 2016 = КоБченко Наталя: Тяжіння: проблема дефініції. Науковий вісник Херсонського державного університету. Т. 25. Херсон, 2016. 9-15.

Кононенко 1975 = Кононенко В. І. Подвійні синтаксичні зв'язки. Украӥнська мова $і$ література в школі 1975/11: 31-42.

КузьМИНьСКА 1981 = КУзьмИНЬСКА Р. Синтаксис двойного подчинения и вопрос об адекватности грамматики зависимостей. АКД. Ленинград, 1981.

Кулик 1965 = Кулик Б. М. Курс сучасної украӥнської літературної мови. Ч. 2. Синтаксис. Київ, 1965.

КУЛЬБАБСЬКА 1998 = КУЛЬБАБСЬКА О. В. Напівпредикативні конструкції в сучасній українській мові. Дисертація канд. філол. наук. Чернівці, 1998.

Мірченко 2004 = Мірченко М. В. Структура синтаксичних категорій. Луцьк, 2004.

Овсянико-Куликовский 1907 = Овсянико-Куликовский Д. Н. Руководство къ изученію синтаксиса русскаго языка. Москва, 1907.

ПАСТУХОВА $1972=$ ПАСТУХОВА Л. С. Расположение в предложении членов с двойной синтаксической связью. В кн.: Проблемы теории членов предложения. Кишинев, 1973. 5-80.

ПЕРЕГІНЕЦЬ 1931 = ПЕРЕГІНЕЦЬ М. СИНтакса простоГо реченНя. В кН.: БУЛАХОВСьКИЙ Л. А. (ред.) Підвищений курс української мови. Харків, 1931. 240-275.

ПЕшКОВСКИй 2001 = ПЕшковСКИй А. М. Русский синтаксис в научном освещении. Москва, 2001.

ПоПовА 2009 = ПоПовА І. С. Фундаментальні категорії метамови українського синтаксису. Одиниия, зв'язок, модель. Дніпропетровськ, 2009.

ПрияткинА 1968 = ПрияткинА А. Ф. О взаимном отношении видов синтаксической связи. Ученые записки Дальневосточного государственного университета. Т. 11. Языкознание. Владивосток, 1968. 39-46.

РАСПОПОВ 1970 = РАСПОПОВ И. П. Строение простого предложения в современном русском языке. Москва, 1970.

СилкинА 1973 = СилкинА 3. А. Опосредствованная синтаксическая связь именных форм с подлежащим и прямым дополнением. АКД. Воронеж, 1973.

СУЛМ 1972 = Сучасна українська літературна мова. Синтаксис. Київ, 1972.

Томусяк 1999 = Томусяк Л. М. Семантико-синтаксична організація речень з дуnлексивами. Дисертація канд. філол. наук. Чернівці, 1999.

ФИНКЕЛЬ-БАЖЕНОВ 1965 = ФИНКЕЛЬ А. М., БАЖЕНОВ Н. М. Курс современного русского литературного языка. Киев, 1965.

ХАСАНОВА 1981 = ХАСАНОВА Р. Н. Тяготение как тип синтаксической связи в современном рУсском языке. АКД. Москва, 1981.

ХРИСТІАНІнОВА 2012 = ХРИСТІАНІнОВА Р. О. Складнопідрядні речення в сучасній українській літературній мові. Київ, 2012.

ХРИСТІАНІнОВА 2015 = ХРИСТІАНІнОВА Р. Подвійний присудок у сучасній українській мові. В кн.: Типологія та функиії мовних одиниць. Т. 2. Луцьк, 2015. 237-249.

ЧЕСНОКОВА 1972 = ЧЕСНОКОВА Л. Д. Конструкции с предикативным определением и структура предложения в современном русском литературном языке. Ростовна-Дону, 1972.

ЧЕСНОКОВА 1980 = ЧЕСНОКовА Л. Д. Связи слов в современном русском языке. Москва, 1980.

ШАХмАТОв 2011 = ШАХмАтов А. А. Синтаксис русского языка. Москва, 2011. 